\title{
IMMUNOFLUORESCENCE ASSAY REACTIVITY PATTERNS OF SERUM SAMPLES PRESENTING INDETERMINATE WESTERN BLOT RESULTS FOR ANTIBODIES TO HIV-1 AND HTLV-I/II IN CORDOBA, ARGENTINA
}

\begin{abstract}
SUMMARY
Serum samples (n: 110) from blood donors and high risk individuals from Cordoba, Argentina with indeterminate HIV-1 and HTLV-I/II Wb profiles were studied for specific antibodies to HTLV-I/II and HIV-1 by indirect immunofluorescence assay (IFA) and for the presence or absence of HIV-1 and HTLV-I/II specific bands by Wb. This study was carried out in order to characterize their putative reactions with HIV-1 and HTLV-I/II proteins and to resolve the retrovirus infection status of these individuals. Results indicated that blood donors sera displaying indeterminate HIV-1 or HTLV-I/II Wb patterns were not immunoreactive to HTLV-I/II and HIV-1 on IFA. However, a high rate of indeterminate HIV-1 and HTLV-I/II Wb samples from high risk individuals had positive HTLV-I/II and HIV-1 IFA results respectively. Our study supports the growing evidence that HTLV-HIV indeterminate seroreactivity in low risk population is due to a cross reaction against nonviral antigens, and in high risk populations the indeterminate samples show serological cross-recognition between HIV-1 proteins and HTLV-I/II proteins on Wb. These results point out the necessity to investigate the HTLV-I/II reactivity in indeterminate HIV-1 samples and viceversa in order to confirm the diagnosis. Finally, this study shows the potential usefulness of IFA in elucidating the status of HIV-1 and HTLV-I/II infection of individuals with indeterminate $\mathrm{Wb}$ profiles, thus enabling resolution of retrovirus infection status.
\end{abstract}

KEYWORDS: Retroviruses; HIV-1; HTLV-I/II; Confirmatory testing; Indeterminate results; Western blot; Indirect immunofluorescence assay.

\section{INTRODUCTION}

Standard practice for HIV-1 and HTLV-I/II antibodies testing in most laboratories involves initial screening and retesting of reactive sera by ELISA or Particle agglutination (PA) followed by Western blot (Wb) confirmation.

Indeterminate patterns on $\mathrm{Wb}$ are common in non HIV-1 or non HTLV-I/II infected people ${ }^{11}$. The proportion of repeatedly anti-HIV-1 and anti-HTLV-I/II samples reactive by ELISA but with indeterminate $\mathrm{Wb}$ patterns has been a subject of concern in the face of reports that range from $13 \%$ to $48 \%$ and $0.02 \%$ to $0.03 \%$ respectively, among blood samples from United States donors ${ }^{12,18}$.

An increasing number of indeterminate results were observed with a higher severity of HIV-related diseases ${ }^{16}$. This increased occurrence of indeterminate results concomitant with the severity of clinical disease is most likely accountable for the well-described phenomenon of declining titers of antibodies to HIV-1 gag and pol antigens with progression of disease ${ }^{1,5,10}$.

The HIV-p24 band, the most commonly observed in indeterminate $\mathrm{Wb}$ analyses ${ }^{13,19}$ is present in $50-70 \%$ of indeterminate $\mathrm{Wb}$, and the only one present in $50 \%$ of indeterminate sera ${ }^{17}$. These gag-reactive antibodies are often a source of false-positive screening ELISA resulting in indeterminate $\mathrm{Wb}$. In many cases, the indeterminate status of a patient will be resolved by the time when a second specimen is tested 3 to 6 months later ${ }^{11}$.

However, the patterns of patients sera with core protein p24 or p24/ p55 reactivity on $\mathrm{Wb}$ for HIV-1 tend to remain indeterminate over a period of many months thereby leaving in limbo the individuals tested and resulting in anxiety and delay in treatment of infected individuals ${ }^{21}$.

The env-reactive indeterminate tests for HIV-1 are about 10 times less frequent than the gag-reactive indeterminate test, among blood donors

Institute of Virology “Dr. J. M. Vanella”, Faculty of Medical Science, National University of Cordoba, Av. Valparaiso s/n, Ciudad Universitaria, 5016 Cordoba, Argentina.

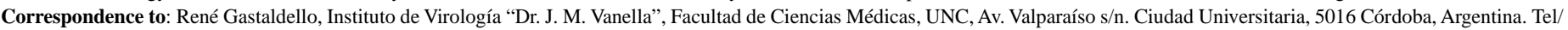
fax: 54-351-4334022; e-mail: sgallego@cmefcm.uncor.edu 


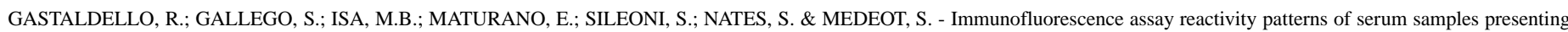
indeterminate Western blot results for antibodies to HIV-1 and HTLV-I/II in Cordoba, Argentina. Rev. Inst. Med. trop. S. Paulo, 43(5):277-282, 2001.

in the United States ${ }^{18}$. Moreover, among volunteer blood donors indeterminate HTLV serologic test results, mostly gag reactive, are found at least as frequently as HTLV-seropositive results ${ }^{12}$.

Another issue of retrovirus serologic diagnosis is the observation of ELISA-negative samples with indeterminate $\mathrm{Wb}$ patterns also has been a matter of concern, since reports of such results are found in as much as $20 \%$ of ELISA-negative HIV-1 blood donors in the United States ${ }^{18}$, and in $11 \%$ of ELISA-negative for HTLV-I/II in the Netherlands ${ }^{23}$.

The rationale for these phenomena is unknown. It is possible that indeterminate reaction patterns are caused by antibodies directed against nonviral antigens originating from the cells in which HIV-1 or HTLV-I/ II are propagated. Cross reaction against unknown HIV-1 and HTLV-I/ II related viruses is another possibility ${ }^{22}$. Alternatively, antibodies reactive only to gag products could be the first evidence of seroconversion after an individual being exposed to and infected with HIV-1 or HTLV-I/II. The clinical and transfusional importance of these indeterminate $\mathrm{Wb}$ results are poorly understood in populations generally considered of low risk ${ }^{2}$.

To better understand the implication of the high frequency of retrovirus indeterminate findings and to provide the individuals with most appropriate information, serum samples from Argentinian blood donors and high risk individuals who had indeterminate HIV-1 and HTLV-I/II Wb profiles were studied for specific antibodies to HTLV-I/II and HIV-1 by indirect immunofluorecence assay (IFA) and for the presence or absence of HIV-1 and HTLV-I/II specific bands on Wb.

\section{MATERIALS AND METHODS}

1. Samples. A total of 110 serum samples corresponding to populations at different risk from Cordoba, Argentina were analyzed (Tables 1 and 2).

\section{Serological assays.}

2.1 Screening test: Enzyme immuno assays: Vironostika HIV UniForm plus O, Organon Teknika and Vironostika HTLV-I/II, Organon

Table 1

Characteristics of the populations studied: risk and serological status

\begin{tabular}{cclcccc}
\hline Group & \multirow{2}{*}{$\mathrm{N}$} & \multicolumn{2}{c}{ Population } & \multicolumn{3}{c}{ Serological status } \\
& & & \multicolumn{2}{c}{ HIV-1 } & \multicolumn{2}{c}{ HTLV-I/II } \\
& & & EIA & Wb & PA & Wb \\
\hline A & 11 & Healthy blood donors & R & I & & \\
B & 50 & High risk for infection* & R & I & & \\
C & 21 & Healthy blood donors & R & N & & \\
D & 7 & High risk for infection* & & & R & I \\
E & 13 & Healthy blood donors & & & R & I \\
F & 8 & Healthy blood donors & & & N & I \\
\hline
\end{tabular}

*: Homosexual men, heterosexual, intravenous drug users, sex workers, hemophiliacs and polytransfused individuals; I: indeterminate; R: reactive; N: negative; EIA: enzyme immuno assay, PA: particle agglutination, Wb: Western blot.
Teknika; Particle agglutination assay: Serodia HTLV-I (Fujirebio Inc., Tokyo, Japan) were used according to the manufacturers instructions.

2.2 Confirmatory test: Western blot assay: NOVA PATH HIV-1 IMMUNOBLOT BIO-RAD, USA and Bioblot HTLV, Biokit S.A., Spain; were used according to the manufacturers instructions. "In house" indirect immunofluorescence assay (IFA): slides prepared with HTLV-I transformed human T cell line (MT-2) and HIV-1 infected H9-IIIB cells were used as source of antigens. IFA was performed according to the procedure previously described by GALLEGO et al. ${ }^{7,8}$.

3. Positivity criteria for HTLV-I/II and HIV-1 antibody detection. Sera were considered positive for HIV-1 or HTLV-I/II antibodies on IFA when characteristic cytoplasmic staining on infected cells and no IFA staining on uninfected cell lines were observed.

A specimen with reactivity on Western blot both to env encoded glycoprotein and gag encoded protein was considered positive for HIV1 or HTLV-I/II antibodies. A specimen was considered indeterminate if it showed any other patterns that did not meet the positivity criteria recommended by the manufacturer, and negative if it showed no antibody reactivity.

Table 2

Summary of HIV-1 and HTLV-I/II indeterminate Western blot profiles of the sera studied

\begin{tabular}{lll}
\hline Group & \multicolumn{2}{c}{ Western blot band * } \\
& HIV-1 (NOVA & HTLV-I/II (Bioblot \\
& PATH HIV-1 & HTLV Biokit, SA, \\
& IMMUNOBLOT & Barcelona, Spain). \\
& BIO-RAD) & \\
\hline
\end{tabular}

\begin{tabular}{lcl}
\hline A (n: 11) & 1 & p65, p24 \\
& 1 & p55, p24 \\
& 8 & p24 \\
& 1 & gp 160 \\
\hline B (n: 50) & 31 & p24 \\
& 9 & gp 160 \\
& 6 & p18, p24 \\
1 & p18 \\
1 & p18, p65 \\
2 & gp 120, gp 160
\end{tabular}

\begin{tabular}{lll}
\hline $\mathrm{D}$ (n: 7) & 5 & $\mathrm{p} 19$ \\
& 2 & rgp 46II, rgp 21 \\
\hline $\mathrm{E}$ (n: 13) & 9 & $\mathrm{p} 19$ \\
& 1 & $\mathrm{p} 24, \mathrm{p} 28$ \\
& 1 & $\mathrm{p} 19, \mathrm{p} 28$ \\
& 1 & $\mathrm{p} 24$ \\
& 1 & $\mathrm{p} 24, \mathrm{p} 19$ \\
\hline $\mathrm{F}$ (n: 8$)$ & 1 & $\mathrm{p} 53, \mathrm{p} 24, \mathrm{p} 19$ \\
& 1 & $\mathrm{p} 24, \mathrm{p} 19$ \\
& 1 & $\mathrm{p} 53, \mathrm{p} 19$ \\
& 5 & $\mathrm{p} 19$ \\
\hline
\end{tabular}

*For band, $\mathrm{p}$ denotes protein, gp denotes glycoproteins, rgp denotes recombinant glycoproteins. 


\section{RESULTS}

Results are shown in tables 3 and 4 . Two of 21 healthy blood donors (group C) with positive reactivity on screening test and HIV-1 Wb negative resulted in inconclusive IFA on HIV-1 (H9 IIIb) cell line, while all the serum samples were negative for HTLV-I/II on IFA (Table 3).

Only one out of 11 healthy blood donors (group A) with indeterminate HIV-1 Wb status was found positive for HIV-1 antibody by IFA. No anti-HTLV-I/II antibodies were detected in this group by IFA (Table 3 ).

Table 3

HTLV-I/II antibodies in individuals with indeterminate or negative HIV-1 Wb status

\begin{tabular}{cccc}
\hline Group & $\mathrm{n}(\%)$ & \multicolumn{2}{c}{ IF antibodies } \\
\cline { 3 - 4 } & & HTLV-I/II (MT-2)* & HIV-1 (H9 IIIb)** \\
\hline A (n: 11) & $10(91 \%)$ & - & - \\
Healthy blood & $1(9 \%)$ & - & + \\
donors & & + & + \\
\hline B & $6(12 \%)$ & - & + \\
$\begin{array}{c}\text { (n: } 50) \\
\text { High risk }\end{array}$ & $6(12 \%)$ & + & - \\
for infection & $25(50 \%)$ & - & - \\
\hline C & $19(90.5 \%)$ & - & $+/-$ \\
$\begin{array}{c}\text { (n: } 21) \\
\text { Healthy blood }\end{array}$ & $2(9.5 \%)$ & - & \\
donors & & & \\
\hline
\end{tabular}

+: Positive; +/-: Inconclusive; -: Negative; *: MT-2 prototipe HTLV-I persistently infected cell line; **: H9-IIIb prototipe HIV-1 persistently infected cell line.

Table 4

HIV-1 antibodies in individuals with indeterminate HTLV-I/II Wb status

\begin{tabular}{|c|c|c|c|c|}
\hline \multirow[t]{2}{*}{ Group } & \multirow[t]{2}{*}{$\mathrm{n}(\%)$} & \multirow{2}{*}{$\frac{\text { Anti HTLV-I/II }}{\text { IFA (MT-2) }}$} & \multicolumn{2}{|c|}{ Anti HIV-1 } \\
\hline & & & IFA (H9) & $\mathrm{Wb}$ \\
\hline $\begin{array}{c}\text { D } \\
(\mathrm{n}: 7)\end{array}$ & $6(86 \%)$ & - & + & + \\
\hline $\begin{array}{c}\text { High risk } \\
\text { for infection }\end{array}$ & $1(14 \%)$ & + & + & + \\
\hline $\begin{array}{c}\text { E } \\
\text { (n: 13) } \\
\text { Healthy blood } \\
\text { donors }\end{array}$ & $13(100 \%)$ & - & - & - \\
\hline $\begin{array}{c}\text { F } \\
(n: 8) \\
\text { Healthy blood } \\
\text { donors }\end{array}$ & $8(100 \%)$ & - & - & - \\
\hline
\end{tabular}

+: Positive; -: Negative; IFA: Indirect Immunofluorescence assay; Wb: Western blot (Novapath HIV-1 immunoblot BIORAD, USA).
Six $(12 \%)$ of the 50 individuals at high risk for infection (group B) with indeterminate HIV-1 Wb were positive for HTLV-I/II and HIV-1 by IFA (Table 3 ); 13 (26\%) were positive only for HTLV-I/II by IFA, 6 (12\%) showed positive reactivity to HIV-1 only, and $25(50 \%)$ were negative for HTLV-I/II and HIV-1 by IFA (Table 3 ).

The 13 healthy blood donors of group E resulted negative for HIV1 by IFA and $\mathrm{Wb}$, while $6(86 \%)$ of the 7 individuals at high risk of infection (group D) were positive for HIV-1 by IFA and one was positive for HTLV-I/II and HIV-1 by IFA (Table 4). Eight blood donors with negative anti-HTLV-I/II screening and indeterminate $\mathrm{Wb}$ results (group F) had negative HTLV-I/II and HIV-1 IFA results (Table 4).

\section{DISCUSSION}

Human T lymphotropic virus and HIV-1 indeterminate serologic results are commonly found in $\mathrm{Wb}$ confirmatory testing. The causes of these reactions, however, remain unsettled.

Blood donors with such serologic reactions are usually rejected for blood donation and there is uncertainty as to what they should be told and how they should be counseled.

Results of the study presented here indicate that most of the blood donors sera that display indeterminate HIV-1 Western blot patterns are not immunoreactive to HTLV-I/II and HIV-1 on IFA, suggesting that this pattern of reactivity is not indicative of HIV-1 or HTLV-I/II infection (Table 3). However, a high rate (26\%) of indeterminate HIV-1 Wb samples from high risk individuals evidenced positive HTLV-I/II IFA results while $12 \%$ tested positive on IFA for both HIV-1 and HTLV-I/II, indicating that these individuals are coinfected with both viruses (Table 3 ).

The absence of reactivity against HIV-1 and HTLV-I/II on IFA of blood donors samples with indeterminate HTLV-I/II patterns indicated that this seroreactivity is unlikely to be due to HTLV-I/II or HIV-1 infection (Table 4). Moreover, the high number (86\%) of HIV-1 Wb positive results among high risk individuals with HTLV-I/II Wb indeterminate results strengthen the HIV-1-infected status of these individuals (Table 4).

In summary, we postulate that indeterminate HIV-1 and HTLV-I/II $\mathrm{Wb}$ patterns in the studied low and high risk populations could be interpreted as it is shown in figures 1 and 2. Our study supports the growing evidence that HTLV-HIV indeterminate seroreactivity in low risk population is due to a cross-reaction against nonviral antigens originating from the cells in which these retroviruses are propagated (Fig. 1 and 2). This interpretation criterion is compatible with that of other authors ${ }^{6,9,12,22,23}$. Antibodies to 244 , gp 120 and gp 160 HIV antigens have been shown to cross-react with human platelets ${ }^{21}$. In addition, certain monoclonal antibodies against HTLV-I p19 have been demonstrated to recognize unique cellular antigens ${ }^{14}$. Cross-reaction against unknown related retrovirus is another possibility.

The non-specificity of HTLV-I/II indeterminate $\mathrm{Wb}$ results in low risk populations was confirmed since the serum samples from eight individuals of group $\mathrm{F}$ that were negatives on anti-HTLV-I/II screening test and $\mathrm{Wb}$ indeterminate, presented negative reaction for HIV-1 and HTLV-I/II by means of IFA (Table 4). 

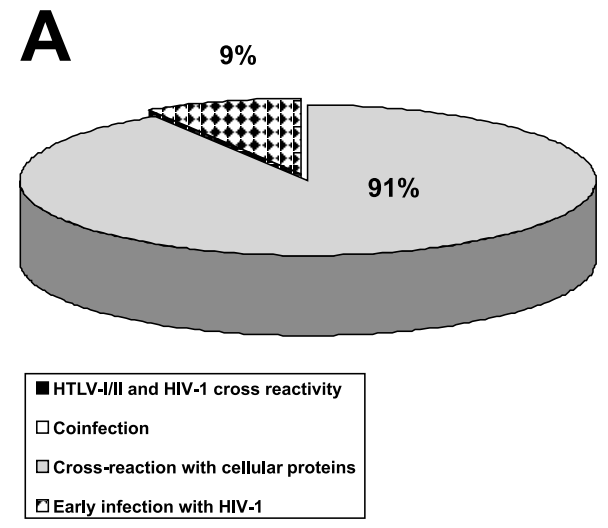

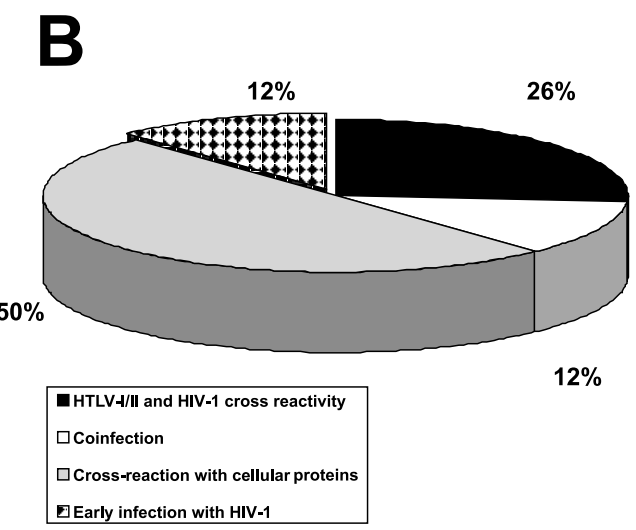

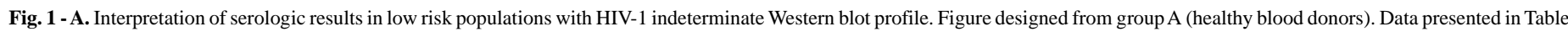


in Table 3 .
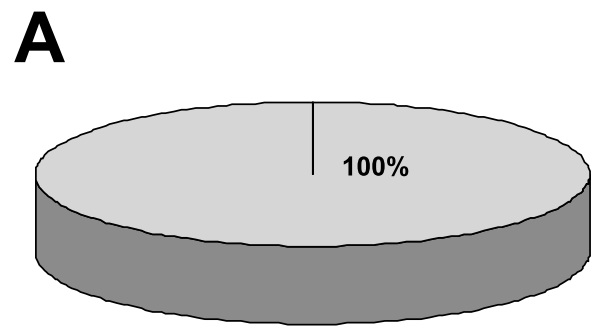

\begin{tabular}{|l|}
\hline HTLV-I/II and HIV-1 cross reactivity \\
$\square$ Coinfection \\
$\square$ Cross-reaction with cellular proteins \\
⿴囗大 Early infection with HIV-1
\end{tabular}





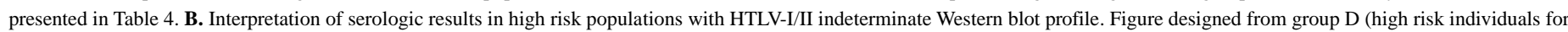
infection). Data presented in Table 4.

Furthermore, although cross-reactivities of HIV-1 antisera with HTLV-I/II antigens have not been reported, the data presented here in high risk populations with indeterminate HIV-1 and HTLV-I/II Wb results (Fig. 1 and 2) show serological cross- recognition between HIV-1 proteins and HTLV-I/II proteins on $\mathrm{Wb}$.

Serological cross-reactivities among many of the lentiviruses have been reported ${ }^{16}$. Moreover, MANZARI et al. have reported data showing cross-reactivity between the sera of patients infected with the human retrovirus HTLV-V and the HIV-1 p24 core antigen on $\mathrm{Wb}^{15}$.

These results pointed out the need to investigate HTLV-I/II reactivity in indeterminate HIV-1 samples and viceversa in order to define the diagnosis.

The high prevalence of HIV and HTLV-I/II in individuals who have risk factors for retrovirus infection together with the policlonal B-cell stimulation characteristic of this population, would be other explanation for the indeterminate patterns. The production of antibodies with cross- reactivity to epitopes of HIV-1 and cellular proteins after polyclonal stimulation of B cells has been reported ${ }^{4}$.

The individuals with HIV-1 or HTLV-I/II Wb indeterminate results who were reclassified as seropositive by IFA (Fig. 1 and 2) emphasize the technical difficulties found in performing available HTLV- HIV confirmatory assays, specially $\mathrm{Wb}$, and illustrates the potential misclassification of HTLV- HIV seropositive individuals as seroindeterminate on this assay. Recent data on HTLV-I seroconverters who were recipients of HTLV-I positive cellular blood products support the appearance of gag antibodies before seroreactivity to native env $\operatorname{protein}^{12}$.

It is interesting that indeterminate profiles for HTLV-I/II or HIV-1 on $\mathrm{Wb}$ showed no differences between the various studied populations. Reports on the association of indeterminate HIV-1 Wb profiles with a positive predictive result should be regarded cautiously ${ }^{3}$.

Indeed, the present study shows the potential usefulness of IFA in elucidating the status of HIV-1 and HTLV-I/II infection of individuals 


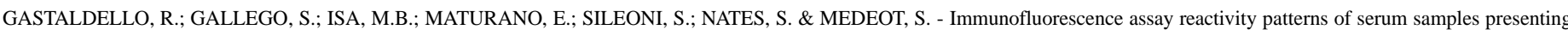
indeterminate Western blot results for antibodies to HIV-1 and HTLV-I/II in Cordoba, Argentina. Rev. Inst. Med. trop. S. Paulo, 43(5):277-282, 2001.

from Argentina with indeterminate $\mathrm{Wb}$ profiles, thus enabling resolution of retrovirus infection status. Moreover, in several countries attempts for reducing the frequency of indeterminate results are done by using IFA test, instead of the $\mathrm{Wb}^{20}$. Also, because of its lower cost, this procedure should be a suitable alternative test for the confirmatory diagnosis of retrovirus infection in Argentina as well as in other developing countries.

\section{RESUMO}

\section{Parâmetros de reatividade de amostras de soro com resultados indeterminados por Western blot para anticorpos contra HIV-1 e HTLV I/II em Córdoba, Argentina}

Amostras de soro sangüíneo (n: 110) de indivíduos de comportamento de risco e doadores de sangue da cidade de Córdoba, na Argentina, com perfis de reactividade para HIV-1 e HTLV-I/II indeterminada por Western blot (Wb), foram estudadas para anticorpos específicos contra HTLV-I/II e HIV-1 por meio do Ensaio de Imunofluorescência Indireta (IFI). Este estudo foi realizado para caracterizar as reações putativas com proteínas HIV-1 e HTLV-I/II e resolver o estado da infecção por retrovírus destes indivíduos. Os resultados mostram que os soros dos doadores sangüíneos que apresentam padrões indeterminados para HTLV-I/II e HIV-1 no Wb não são reagentes contra HTLV-I/II e HIV-1 por IFI. Mas, um alto índice de amostras de individuos com alto risco com resultado indeterminado no $\mathrm{Wb}$ para HIV1 e HTLV-I/II apresentaram resultados positivos para HTLV-I/II e HIV1 por IFI, respectivamente. Nosso estudo sugere que a reatividade indeterminada para HTLV-HIV na população de baixo risco deve-se a uma reação cruzada contra antígenos não virais; e que na população de alto risco as amostras indeterminadas apresentam reação cruzada entre as proteínas HIV-1 e HTLV-I/II no Wb. Estes resultados indicam que se faz preciso pesquisar a reatividade de HTLV-I/II nas amostras indeterminadas de HIV-1 e vice-versa, para confirmar o diagnóstico. Por último, este trabalho mostra a utilidade potencial da IFI para determinar o estado de infecção HIV-1 e HTLV-I/II dos indivíduos com perfis indeterminados por $\mathrm{Wb}$, permitindo assim, a resolução do estado real de infecção por retrovírus.

\section{ACKNOWLEDGEMENTS}

The authors are grateful to Dr. Renu B. Lal and Horacio Salomon for providing the cell lines and to Dr. H. Bepre for providing the sera. We are also grateful thank for the collaboration of Dr. Marta Contigiani who facilitated us the use of the biological safety facilities.

This work received financial support from the Council of Science and Technology of the National University of Cordoba, Argentina; The Council of Science and Technology of Cordoba Province (CONICOR) and Dr. Raquel Elsa Rosso from the DASPU laboratory, UNC. René Gastaldello and Sandra Gallego were supported by fellowships from National University of Cordoba and CONICOR respectively.

\section{REFERENCES}

1. ALLAIN, J.P.; LAURIAN, Y.; PAUL, D.A. et al. - Long-term evaluation of HIV antigen and antibodies to p24 and gp41 in patients with hemophilia. Potential clinical importance. New Engl. J. Med., 317: 1114-1121, 1987.
2. CARNEIRO-PROIETTI, A.B.F.; CUNHA, I.W.; SOUZA, M.M. et al. - HIV-1/2 indeterminate Western blot results: follow up of asymptomatic blood donors in Belo Horizonte, Minas Gerais, Brazil. Rev. Inst. Med. trop. S. Paulo, 41: 155-158, 1999.

3. Ceballos, A.; DeVito, C.; PAMPURO, S. et al. - Evaluación de la inmunofluorescencia indirecta como prueba suplementaria para el diagnóstico de la infección por HIV-1. Rev. argent. Microbiol., 30: 56-63, 1998.

4. CELUM, C.; COOMBS, R.W.; JONES, M. et al. - Risk factors for repeatedly reactive HIV-1 EIA and indeterminate Western blots. A population-based case-control study. Arch. intern. Med., 154: 1129-1137,1994.

5. FROSNER, G.G.; ERFLE, V.; MELLERT, W. \& HEHLMANN, R. - Diagnostic significance of quantitative determination of HIV antibody specific for envelope and core proteins. Lancet, 1: 159-160, 1987.

6. FUKUSHIMA, A.; UENO, H. \& FUJIMOTO, S. - Antigenic cross-reactivity between human T lymphotropic virus type I (HTLV-I) and retinal antigens recognized by T cells. Clin. exp. Immunol., 95: 459-464, 1994.

7. GALLEGO, S.; RECALDE, A.; GASTALDELLO, R. et al. - Kinetics study of human retrovirus antigens expression in $\mathrm{T}$ lymphocytic cell lines by indirect immunofluorescence assay. Viral Immunol., 10: 149-157, 1997.

8. GASTALDELLO, R.; GALLEGO, S.; ISA, M.; NATES, S. \& MEDEOT, S. - Efficiency of indirect immunofluorescence assay as a confirmatory test for the diagnosis of human retrovirus infection (HIV-1 and HTLV-I/II) in different at risk populations. Rev. Inst. Med. trop. S. Paulo, 41: 159-164, 1999.

9. GENESCA, J.; SHIH, J.W.; JETT, B.W. et al. - What do Western blot indeterminate patterns for human immunodeficiency virus mean in EIA-negative blood donors? Lancet, 28: 1023-1025, 1989.

10. GOUDSMIT, J.; LANGE, J.; PAUL, D.A. \& DAWSON, G.J. - Antigenemia and antibody titers to core and envelope antigens in AIDS, AIDS-related complex, and subclinical human immunodeficiency virus infection. J. infect. Dis., 155: 558-560, 1987.

11. JOSEPHSON, S.L.; SWACK, N.S.; RAMIREZ, M.T. \& HAUSLER Jr, W.J. -Investigation of atypical Western blot (immunoblot) reactivity involving core proteins of human immunodeficiency virus type I. J. clin. Microbiol., 27: 932-937, 1989.

12. KHABBAZ, R.; HENEINE, W.; GRINDON, A. et al. - Indeterminate HTLV serologic results in U.S. blood donors: are they due to HTLV-I or HTLV-II? J. AIDS hum. Retrov., 5: 400-404, 1992.

13. KLEINMAN, S. - The significance of indeterminate Western blots for HIV-1. Update, testing in the Blood bank, 2: 3-5, 1988.

14. LAIRMORE, M. \& LAL, R. - Other human retrovirus infections: HTLV-I and HTLV-II. In: SCHOCHETMAN, G. \& GEORGE, J., ed. AIDS testing: methodology and managment. 1991. p. 168-188.

15. MANZARI, V.; GISMONDI, G.; BARILLARI, S. et al. - HTLV-V: a new human retrovirus isolated in a Tac-negative T-cell lymphoma/leukemia. Science, 238: 1581-1583, 1987.

16. NG, V.L.; CHIANG, C.S.; DEBOUCK, C. et al. - Reliable confirmation of antibodies to Human Immunodeficiency Virus type 1 (HIV-1) with an enzyme-linked immunoassay using recombinant antigens derived from the HIV-1 gag, pol, and env genes. J. clin. Microbiol., 27: 977-982, 1989.

17. POVOLOTSKY, J.; GOLD, J.W.; CHEIN, N.; BARON, P. \& ARMSTRONG, D. Differences in human immunodeficiency virus type 1 (HIV-1) anti p24 reactivities in serum of HIV-1 infected and uninfected subjects: analysis of indeterminate Western blot reactions. J. infect. Dis., 163: 247-251, 1991.

18. RAMIREZ, E.; URIBE, P.; ESCANILLA, D.; SANCHEZ, G. \& ESPEJO, R.T. -Reactivity patterns and infection status of serum samples with indeterminate Western immunoblot tests for antibody to human immunodeficiency virus type 1. J. clin. Microbiol., 30: 801-805, 1992. 
GASTALDELLO, R.; GALLEGO, S.; ISA, M.B.; MATURANO, E.; SILEONI, S.; NATES, S. \& MEDEOT, S. - Immunofluorescence assay reactivity patterns of serum samples presenting indeterminate Western blot results for antibodies to HIV-1 and HTLV-I/II in Cordoba, Argentina. Rev. Inst. Med. trop. S. Paulo, 43(5):277-282, 2001.

19. RANKI, A.; JOHANSSON, E. \& KROHN, K. - Interpretation of antibodies reacting solely with human retroviral core proteins. New Engl. J. Med., 318: 448-449, 1988.

20. REESINK, H.W. \& ENGELFRIET, C.P. - What are the consequences of indeterminate results in confirmatory test for antibodies against transmissible viruses? Vox sang. (Basel), 73: 97-104, 1997.

21. SETHOE, S.Y.; LING, A.E.; SNG, E.H.; MONTERO, E.H. \& CHAN, R.K.. - PCR as a confirmatory test for human immunodeficiency virus type 1 infection in individuals with indeterminate Western blot (immunoblot) profiles. J. clin. Microbiol., 33: 30343036, 1995.
22. WHETSTONE, C.A.; SAYRE, K.R.; DOCK, N.L. et al. - Examination of whether persistently indeterminate human immunodeficiency virus type 1 Western immunoblot reactions are due to serological reactivity with bovine immunodeficiency-like virus. J. clin. Microbiol., 30: 764-770, 1992.

23. ZAAIJER, H.; CUYPERS, H.; DUDOK de WIT, C. \& LELIE, P.N. - Results of 1-year screening of donors in the Netherlands for human T-lymphotropic virus (HTLV) type I: significance of Western blot patterns for confirmation of HTLV infection. Transfusion (Philad.), 34: 877-880, 1994.

Received: 26 September 2000

Accepted: 05 July 2001 